DOI: https://doi.org/10.32839/2304-5809/2021-5-93-51

удК 781.7

Мокрогуз І.М., Бондаренко В.В., Осипенко Я.С.

Чернівецький національний університет імені Юрія Федьковича

\title{
НАРОДНО-ІНСТРУМЕНТАЛЬНЕ МИСТЕЦТВО БУКОВИНИ: ІСТОРІЯ ТА ТРАДИЦІЇ
}

Анотація. У статті висвітлюються історичні передумови виникнення і подальшого розвитку жанру народно-інструментального мистецтва на Буковині. Крізь призму різноманітності етнічних культур, що відтворюють народні традиції та звичаї населення Буковини, аналізуеться виконавська діяльність лаутарів і троїстих музик, їх роль у збереженні та збагаченні традицій народно-інструментального виконавства, примноженні культурних надбань. Наголошується на важливості підтримки численних територіальних музичних товариств, об'єднань, громад органами державної, місцевої влади щодо популяризації діяльності народно-інструментальних колективів шляхом залучення їх до участі у міжнародних фестивалях, конкурсах-оглядах, культурно-мистецьких заходах із метою їх підтримки і подальшого творчого розвитку народного музичного мистецтва нашого краю.

Ключові слова: Буковина, народно-інструментальне мистецтво, виконавство, лаутари, троїсті музики, музикування, традиції, звичаї, фольклорно-етнографічні фестивалі, колективи народно-інструментальної музики.

Mokroguz Inna, Bondarenko Vitalii, Osypenko Yaroslav

Yuriy Fedkovych Chernivtsi National University

\section{FOLK-INSTRUMENTAL ART OF BUKOVYNA: HISTORY AND TRADITIONS}

Summary. Modern Bukovyna belongs to the region of Ukraine where, along with Ukrainians, representatives of 65 nationalities and ethnic groups historically reside. The music environment of the region and its development has always been influenced by folk tradition sand multiculturalism. The general tolerance and mutual respect of ethnic cultures for national traditions and customs have been shaped throughout the history of state formation.Folk music, born in the lands of Bukovyna from ancient times till the present, has accumulated cultural and everyday traditions and customs of the historical periods. The article covers the historical prerequisites of the emergenceand further development of the genre of folk-instrumental art in the Bukovyna region. The performance of lautari and troist musicians, their role in preserving and enriching the traditions of folk-instrumental performance, and increasing cultural heritage has been analyzed considering the diversity of ethnic cultures that reproduce the folk traditions and customs of the population of Bukovyna. The study outlines the traditions of folk-instrumental music-making, typical ensemble compositions of the bands in the Bukovyna region. According to historical sources, its origin is connected with the spreading music activity of the traveling families of musicians in the territories of Bessarabia, Bukovina and Transcarpathian lands. Lautari are Moldovan, Romanian, and often Gypsy instrumentalists and singers. The movement of lautari in the second half of the XVI and the beginning of the XVII centuries coincided with the spread in the territories of Western Ukraine of such a phenomenonas troist musicians. This is the time when authentic forms and typical compositions of ensemble performances are affirmed. The article analyzes the development process of folk-instrumental art of lautari and troist musicians in the Bukovyna region and its further transformation during the XX-XXI centuries. The paper emphasizes the importance of the support of the numerous local music societies, associations, and communities by state and local aut horities by in volving them to participate in international festivals, competitions, cultural and artistice vents in order to popularize the activities of folk and instrumental group sand ensure further creative development of folk music art of Bukovyna region.

Keywords: Bukovyna, folk-instrumental art, performance, lautari, troist musicians, music, traditions, customs, folk-ethnographic festivals, folk-instrumental music groups.

Постановка проблеми. Аналізуючи процес розвитку народно-інструментального мистецтва в історичному просторі актуальним є питання подальшого дослідження становлення та еволющії інструментального виконавства буковинського краю в контексті історичних суспільно політичних змін на всіх етапах державотворення, вплив яких був не простим та однозначним. Народно-інструментальна музика Буковини, як один iз жанрів музичного фольклору, є вихідною точкою виміру рівня збереження нематеріальної духовної спадшини, що передаеться з покоління в покоління та набутих традицій етнічних спільнот нашого краю. Діяльність народних музик, їх музикування, географія поширення лаутарів, троїстих музик на Буковині в історичному, етнічному вимірі є предметом актуальності подальших досліджень.

Аналіз останніх досліджень і публікацій. Серед наукових досліджень, які розкривають тему розвитку народно-інструментального мистецтва у Карпатському регіоні i, зокрема, на Буковині варто згадати праці В. Джімера, Ю. Гіни, М. Гакмана, К. Демочка, О. Залуцького, А. Іваницького, А. Кушніренка, I. Мацієвського, I. Мокрогуз, Л. Пасічняк, І. Сеньківа, М. Черепанина.

Окремо про буковинських авторів. К. Демочко у книзі «Музична Буковина» висвітлюе історію розвитку музичного мистецтва буковинського краю, зокрема, народно-інструментального. О. Залуцький у своїх розвідках продовжив дослідження музичного мистецтва Буковини, що втілилося у створені серії випусків (більше десяти збірників) хрестоматії з «Музичного краєзнавства Буковини». В. Джімер все своє плідне, творче життя збирав музичний фольклор буковинського краю, зокрема, Путильщини, який поступово розміщується в серії випусків хрестоматії «Твори для оркестру народної та інструмен- 
тальної музики» навчального посібника з курсу «Оркестровий клас» на кафредрі музики ЧНУ ім. Ю. Федьковича (укладач В. Бондаренко). Практичні напрацювання народно-інструментальної музики відтворені в аранжуваннях та власних творах викладачів кафедри музики ЧНУ: Ю. Гіни, М. Гакмана, І. Мокрогуз, що опубліковані різними видавництвами.

Виділення невирішених раніше частин загальної проблеми. Дослідження етапів становлення розвитку народно-інструментального мистецтва буковинського краю не обмежується лише діяльністю лаутарів та троїстих музик, тому тема дослідження передбачає подальші наукові розвідки і потребує більшого висвітлення, аналізу з боку науковців, істориків-дослідників.

Формулювання цілей статті. Одне 3 головних завдань - висвітлити умови, що вплинули на формування та розвиток народно-інструментального мистецтва Буковини на основі історичних досліджень, сучасних наукових праць та медіа ресурсів. Саме тому, головною метою $є$ розкрити основні аспекти виконавської діяльності, проаналізувати вплив лаутарів, троїстих музик на фрормування та розвиток сталих традицій у сучасному народно-інструментальному мистецтві Буковини.

Виклад основного матеріалу дослідження. Сучасна Буковина належить до регіону України, в якому поруч з українцями історично проживають «представники 65 національностей i народностей» [2, с. 303]. Музичне середовище краю, його розвиток завжди знаходилось під впливом народних традицій і «стихійної мультикультурності» [4, с. 47]. Загальна толерантність i взаємоповага етнічних культур щодо нащіональних традицій і звичаїв у соџіально-побутовому просторі формувалася протягом всієї історії державотворення.

Діяльність численних музичних товариств, об'єднань, громад свідчить про підтримку органами державної, місцевої влади стратегії щодо збереження та примноження національних традицій, культурних надбань, духовних цінностей етнічних спільнот краю, чим сприяють формуванню їх неповторності, самобутності. Населення буковинського краю репрезентуе традиції та звичаї багатьох національних культур: білоруської, вірменської, єврейської, німецької, польської, російської турещької та інших. Вплив української культури у гармонічному поєднанні 3 австрійською, румуно-молдовською знаходить своє вираження у загальному мелосі та колориті музичного фольклору Буковини.

Традиції народно-інструментального музикування на Буковинських землях сягають від другої половини XVI - першої половини XVII століття. Час виникнення, згідно історичних джерел, пов'язують 3 поширенням музичної діяльності на територіях Бесарабії, Буковини, земель Закарпаття мандруючих музикантів. Лаутари або леутари (pyм. lăutari) - традиційно це молдовські, румунські, часто циганські інструменталісти та співаки. Назва «лаутари» походить від слова «леута» або «алеута» - старовинного щипкового музичного інструменту. У Молдові та Румунії це слово стало називним для гуртів народних музикантів, переважно виконавців на струнних інструментах. Лаутари своєю грою супроводжували народні свята, весілля, гуляння, різноманітні театралізовані дійства. Їх музична діяльність у свій час вплинула на творчість професійних румунських композиторів-скрипалів Дж. Енеску та Г. Дініку.

Як різновид народно-інструментального музикування мистецтво історично ствердилося у побуті населення Буковини. Виконавські традиції лаутарів продовжують численні оркестри молдавської і буковинської народно-інструментальної музики. У наш час лаутари є зберігачами етнічного музичного фольклору та історичної манери виконання на Буковині та прилеглих прикордонних територіях [9].

Рух лаутарів у другій половині XVI - на початку XVII століття, згідно історичних джерел, співпадає з поширенням такого явища на територіях Західної України, як троїсті музики. Народно-інструментальне мистецтво троїстих музик, швидко зазнало популярності і на буковинських землях. Саме у той час стверджуються автентичні форми та типові склади ансамблевого виконавства троїстої музики [7, с. 133].

Перші склади троїстих музик відповідали назві і складалися 3 трьох учасників. Діяльність троїстих музик була тісно пов'язана 3 географрією побутування і мала характерні територіальні ознаки, що відображалося на особливостях репертуару та місцевому колориті музикування. Склади народних музик різнилися і варіювалися згідно існуючих традицій місцевого виконавства. Типовими на Буковині, як і на території Карпатського регіону були народно-інструментальні тріо за участю скрипки, цимбалів, бубна; скрипки, сопілки, цимбалів; скрипки, сопілки, баса; скрипки, цимбалів, бухала (барабана із тарілкою) [5].

В описах про хрестини, сільські празники, вечори молоді, танщі, розколяду, входини, «відэідини», календарні та сімейні свята, весілля, похорон гуцулів, який опублікував В. Шухевич, знаходимо згадки про ансамблі, так звані «музики» та інструменти, що користуються популярністю у даній етнічній спільноті: дуду (козу), дзвоники, сопілку, трембіту, цимбали, дримбу [8].

Основною функцією ансамблю троїстих музик дослідники визначають виконання традищійних інструментальних творів для супроводу танців. Виконавський репертуар подібних народно-інструментальних гуртів охоплює всі жанри: від календарнообрядової музики до сольно-інструментальної.

Здавна музичні традиції тут передавалися 3 покоління в покоління на слух. Не знаючи нотної грамоти, здібні до музики буковинці віками інтуїтивно переймали своєрідне виконання мелодій і всю палітру супроводу, гармонії і ритму [6]. Традищійно типова форма побудови виконавських функцій при музикуванні мала такий вигляд: мелодія (скрипка, сопілка), гармонічний супровід (цимбали, бас), метроритмічна фрункція (народні ударні інструменти).

У порівнянні з минулим сучасні склади троїстих музик значно розширились. Кількість музикантів залежить від учасників гурту і може включати до складу троїстих музик різноманітні інструменти, що задіяні до музикування: різновиди сопілок, фрлейту, кобзу, мандоліну, гітару, кларнет, трубу, саксофрон, тромбон, акордеон.

Сучасні Різдвяні колядки, щедрівки, вертепно-маланкові дійства, супроводжуються ін- 
струментальним супроводом 3 різноманітними однорідними та розширеними складами музикантів-виконавців, в яких поеднуються струнні, клавішні, дерев'яні та мідні духові інструменти, дзвоники, ріг, трембіта, фрлояра, скрипка, бас, цимбали, бубон, баян» [8].

$\mathrm{V}$ другій половині XX - початку XXI століть у виконавстві троїстих музик відбувається трансформація жанрів інструментальної, вокально-інструментальної народної музики, автентичного фольклору (створюються франтазії, рапсодії, п’еси, в'язанки), з'являються авторські композиції.

Якщо раніше у склади троїстих музик об'єднувалися обдаровані місцеві музиканти самоучки, то на сучасному етапі розвитку ансамблів троїстих музик керівники і виконавці колективів дедалі частіше мають профресійну виконавську освіту, успішно поєднуючи педагогічну і концертно-виконавську діяльність.

3 видозміною інструментальних складів троїстих музик урізноманітнюються назви учасників гуртів (весільна, гуцульська, велика капела). Різновид розширеного складу троїстих музик отримав назву «велика музика». Відомий з таких колективів на Буковині - ансамбль троїстих музик із с. Глиннищі Кіцманського району (родина Богданюків).

Виконавський репертуар, як відзначалося раніше, тісно пов'язаний з етносом проживаючого на території населення та сталими народно-побутовими традиціями. У місцевостях 3 переважно румуно-молдовським населенням народно-інструментальні склади, подібні до троїстих музик, традиційно прийнято називати лаутарами.

Жанрові різновиди народно-інструментального виконавства перетинаються у соціальнокультурному просторі, підтримуючи традиції i подальший розвиток музичного мистецтва краю. Лаутари традиційно музикували сім'ями та родинами і саме вони могли започаткувати виконання вокальних мелодій в інструментальному супроводі, що у подальшому стало частиною їх загального виступу. Обидва види народно-інструментального виконавства у концертній діяльності пропагують обрядову та розважальну танцювально-інструментальну музику територіальних громад, в яких вони проживають.

Завдяки географічному розташуванню, народно-інструментальне мистецтво Буковини вирізняеться яскравою самобутністю та неординарністю. Значна кількість ансамблів інструментальної музики буковинського краю вражає своєю харизматикою, нестандартною побудовою композищій. Буковинські народно-інструментальні колективи постійно гастролюють, приймаючи участь у різноманітних міжнародних фрестивалях у рамках культурних обмінів з іншими державами та прилеглими прикордонними територіями.

Традиційними для Буковини $є$ фолольклорно-етнографрічні фрестивалі на зразок «Буковинських зустрічей» та Міжнародного гуцульського фрестивалю.

Фестиваль «Буковинські зустрічі», що започаткований у 1989 році нащадками вихідців із Буковини у Польщі, репрезентує автентичний фольклор, багатобарвну культуру буковинського краю в Україні та поза її межами. Культурномистецький захід щорічно відбувається у Чернівцях та прилеглих прикордонних територіях кра- їн Карпатського регіону за участю українських, румунських, молдовських, польських, угорських та словацьких та інших народних колективів.

Міжнародний гуцульський фрестиваль, заснований 1991 року, що традищійно відбувається в містах густо заселених корінним етнічним населенням Чернівецької (Вижниця, Путила), Закарпатської (Рахів), Івано-Франківської (Верховина, Косів, Коломия, Надвірна, Яремче) областей, відтворюе найбільш поширені звичаї гуцулів: проводи на полонину, гуцульське весілля, релігійні календарні свята, як Різдво 3 новорічно-різдвяними колядками та щедрівками («Василя», «Водохреща», "Маланки», гуцульська «Розколяда») та Великдень (Пасха) з великодніми гаївками [3].

На повагу і визнання сьогодні заслуговують численні колективи народно-інструментальної музики нашого краю. Яскраве, самобутне мистецтво Буковини демонструють аматорські оркестри народних інструментів:

"Аідішенешуме» («Сврейська душа») Чернівецького благодійного фонду "Хесед-Шушана", «Буковина» Центрального палацу культури м. Чернівщі; «Валя Прутулуй», Будинку культури с. Горбова Герцаївського району; вокально-інструментального гурту «Джерело» педагогічного коледжу Чернівецького національного університету ім. Ю. Федьковича; «Глинницькі музики» с. Глинниця Кіцманського району, «Ізвораш» Будинку культури с. Костичани Новоселищького району, «Мерцішор» Чернівецкого клубу мікрорайону «Красногорівка», «Мугурел» Будинку культури с. Опришени Глибоцького р-ну, «Передзвін» районного Палацу культури м. Заставна; «Плаюл Херцей» районногоБудинку культурим. Герца, «Полонина» Будинку культури м. Путила, Фрейлехс 3 Чернівців»- оркестру єврейської музики; «Трандафрір» Будинку народної творчості i дозвілля с. Волока Глибоцького р-ну [1].

Висновки i пропозиції. Народна музика, що народжувалась на землях Буковини з давніхдавен і до наших часів постійно акумулювала традиції і звичаї в історичному просторі. У народно-інструментальному мелосі, що складає основу репертуару, часто прослуховуються стародавні мотиви культур різних народів, що проживали в нашій місцевості. Найбільш виразно вони проявляються у колядках, весільних та інших обрядах та хрестинах. Це є основним джерелом їх розвитку та духовності, запорукою подальшого існування.

Будучи носіями народної музичної культури, лаутари, троїсті музики займають провідне місце у збереженні та примноженні народно-інструментального музикування на Буковині. Буковина за своєю національною ідентичністю - край, багатий i обдарований традиціями, звичаями, самобутністю багатьох національних культур. Мистецтво буковинських народних музикантів завжди отримувало шанування і визнання не тільки в Україні, а й далеко за її межами. Фольклорні фрестивалі, огляди, конкурси, концерти, в яких постійно приймають участь народно-інструментальні колективи, покликані збагачувати скарби духовної спадщини, фрормувати духовні цінності підростаючого покоління, пропагувати національні традиції різних народів, адже саме у цьому полягає особливість культурного розвитку буковинського краю. 


\section{Список літератури:}

1. Бондаренко В.В. Народна оркестрова музика Буковини: тенденщії та реалії сьогодення. Науковий вісник Чернівецького університету : Збірник наукових пращь. Вип. 719. Педагогіка та психологія. Чернівці : Чернівецький нац. ун-т, 2014. С. 37-41.

2. Ботушанський В.М., Біленкова С.В., Добржанський О.В. та ін. Чернівці: Історія і сучасність (Ювілейне видання до 600-річчя першої писемної згадки про місто) : Кол. монографрія / за заг. ред. В.М. Ботушанського. Чернівці : Зелена Буковина, 2009. 303 с.

3. Іваницький A.I. Український обрядовий фрольклор західних земель. Регіональна музична антологія. Вінниця : Нова книга, 2012. 618 с.

4. Круглашов А.М. Буковинська етнополітична мозаїка. Історична спадщина та сучасні тенденції. Політичний менеджмент. Інститут політичних і етнонаціональних досліджень ілені I.Ф. Кураса НАН Украӥни. 2004. № 2. C. 47-67.

5. Маціевський I.В. Музичні інструменти гуцулів. Вінниця : Нова книга, 2012. 464 с.

6. Мішалов В.Ю. «Музичні інструменти українського народу» Гната Хоткевича. Вступна стаття до видання «Гнат Хоткевич. Музичні інструменти українського народу». Харків, 2002. С. 5-9.

7. Пасічняк Л.М. Троїста музика в народно-інструментальному мистецтві України ХХ століття. Мистецтвознавство. Вісник Прикарпатського університету. Івано-Франківськ : Плай, 2002. С. 133-144.

8. Шухевич В.О. Гуцульщина : В 2 ч. 2-е вид. / Репринтне видання 1899-1901. Верховина : Журнал «Гуцульщина», 1997. 352 c.

9. Лаутари. URL: https://uk.wikipedia.org/wiki/

\section{References:}

1. Bondarenko V.V. (2014) Narodna orkestrova muzyka Bukovyny: tendenciyi ta realiyi sogodennya [Folk orchestral music of Bukovina: trends and realities of today]. Naukovyi visnyk Chernivetskoho universytetu: Zbirnyk naukovykh prats. Vyp. 719. Pedahohika ta psykholohiia, vol. 719, pp. 37-41.

2. Botushanskyi V.M., Bilenkova S.V., Dobrzhanskyi O.V. ta in. (2009) Chernivtsi: Istoriia $i$ suchasnist (Yuvileine vydannia do 600-richchia pershoi pysemnoi zghadky pro misto) [Chernivtsi: History and modernity (Jubilee edition to the 600th anniversary of the first written mention of the city)]: Kol. monohrafiia / za zah. red. V.M. Botushanskoho. Chernivtsi: Zelena Bukovyna, p. 303. (in Ukrainian)

3. Ivanyczkyj A.I. (2012) Ukrayinskyj obryadovyj folklor zaxidnyx zemel. Regionalna muzychna antologiya [Ukrainian ritual folklore of western lands. Regional musical anthology]. Vinnitsa: New Book, p. 618. (in Ukrainian)

4. Kruhlashov A.M. (2004) Bukovynska etnopolitychna mozaika. Istorychna spadshchyna ta suchasni tendentsii [Bukovina ethnopolitical mosaic. Historical heritage and current trends]. Politychnyi menedzhment. Instytút politýchnykh i etnonatsionálnykh doslídzhen imeni I.F.Kúrasa NAN Ukrainy, vol. 2, pp. 47-67.

5. Matsiievskyi I.V. (2012) Muzychni instrumenty hutsuliv [Musical instruments of Hutsuls]. Vinnitsa: New Book, p. 464. (in Ukrainian)

6. Mishalov V.Yu. (2002) «Muzychni instrumenty ukrainskoho narodu» Hnata Khotkevycha ["Musical instruments of the Ukrainian people" by Gnat Hotkevych]. Vstupna stattia do vydannia "Hnat Khotkevych. Muzychni instrumenty ukrainskoho narodun. Kharkiv, pp. 5-9.

7. Pasichniak L.M. (2002) Troista muzyka v narodno-instrumentalnomu mystetstvi Ukrainy XX stolittia [Triple music in folk and instrumental art of Ukraine of the XX century]. Mystetstvoznavstvo. Visnyk Prykarpatskoho universytetu. Ivano-Frankivsk: Plai, pp. 133-144.

8. Shukhevych V.O. (1997) Hutsulshchyna: V 2 ch. 2-e vyd. [Gutsultshtina: In two parts, 2nd edition]. Repryntne vydannia 1899-1901. Verkhovyna: Zhurnal «Hutsulshchyna», p. 352

9. Lautari. URL: https://uk.wikipedia.org/wiki/ 